Egyptian Journal of Aquatic Biology \& Fisheries

Zoology Department, Faculty of Science,

Ain Shams University, Cairo, Egypt.

ISSN $1110-6131$

Vol. 25(1): $665-679$ (2021)

www.ejabf.journals.ekb.eg

\title{
Reproductive biology of the two commercially important grouper species Epinephelus summana and $E$. polyphekadion in the Egyptian coast of the Red Sea
}

\author{
Hanan M. Osman*, Azza A. El Ganainy, Amgad M. Shaaban and Mahmoud A. Saber \\ National Institute of Oceanography and Fisheries, Egypt \\ *Corresponding author: hanan_zxcv@yahoo.com
}

\begin{abstract}
ARTICLE INFO
Article History:

Received: Jan. 16, 2021

Accepted: Feb. 8, 2021

Online: Feb. 14, 2021
\end{abstract}

\section{Keywords:}

Grouper fishes;

Epinephelus summana;

E. polyphekadion;

Reproductive biology;

Sex ratio;

Sexual pattern;

Spawning season;

Fecundity

\section{ABSTRACT}

Groupers have a high contribution to the coral reef community structure and balance. Various aspects of the reproductive biology of the two commercially species Epinephelus summana and Epinephelus polyphekadion were investigated for the first time in the Red Sea. A total of 246 individuals (125 E. summana and 121 E. polyphekadion) were collected from different landing sites on the Egyptian Red Sea from 2017 to 2019. Results showed that females outnumbered males in both species as the overall sex ratios (males: females) were $1: 1.2$ and $1: 1.3$ for $E$. summana and $E$. polyphekadion respectively. The size structure of $E$. summana and the presence of bisexual individual $(34 \mathrm{~cm}$. TL) provide strong evidence that this species is a protogynous hermaphrodite. For the camouflage grouper, no evidence was obtained to confirm hermaphroditism. Seasonal variations in gonado-somatic index revealed that the spawning occurred during April and May for $E$. summana and during May and June for $E$. polyphekadion. Lengths at first maturity $\left(\mathrm{L}_{\mathrm{m} 50}\right)$ for male and female of E. summana were 23.0 and $23.5 \mathrm{~cm}$, respectively. However, $\mathrm{L}_{\mathrm{m} 50}$ for male and female E. polyphekadion were 27.1 $\mathrm{cm}$ and $28.8 \mathrm{~cm}$, respectively. Some of the spawning aggregation sites along the Egyptian Red Sea coast were identified by using information from experienced fishers. Both species were characterized by high fecundity. This study concluded that the results of the life history characteristics of these species are considered as good data, will add to the requirements of managing the exploitation of these valuable resources.

\section{INTRODUCTION}

Groupers (Family Serranidae, subfamily Epinephelinae) have more than 159 species belonging to 15 genera. They are widely distributed in tropical and subtropical areas (Nelson, 1994). They are known as coral reef species (Ambak et al., 2012). Groupers are top predators with an important role in coral reef communities structure (Grandcourt et al., 2009). Groupers include the most target species with high marketable value in the Red Sea and the Gulf of Suez (El Ganainy, 2017). They are highly overexploited species because of their spawning aggregation behavior which made them vulnerable to fishing. Several medium to large bodied groupers aggregate annually for spawning at specific sites in association with certain lunar phases (Sadovy, 2005; Teruya et al., 2008; Khasanah et al., 2019). Aggregations are commonly composed of few dozen 
to 100,000 individuals that may migrate over long-distances of several to more than 240 $\mathrm{km}$ for spawning (Carter et al., 1994; Johannes et al., 1999; Bolden, 2000). The management of grouper stock should be at level of species because they have variation in biological characteristics (Abdul Kader et al., 2016). Vulnerability to fishing can be managed by information about the life history and reproductive biology (Kandula et al., 2015).

Groupers form an important part of reef fisheries landings in the Red Sea, where they mainly caught by hooks and lines and gill nets. Recorded landings of grouper species reached 3708 tons in 2016 constituting about $7.3 \%$ of all fish landings in the Egyptian Red Sea (GAFRD, 2017).

This study is the first detailed investigation of the reproductive biology of $E$. summana and E. polyphekadion in the Red Sea. The study aimed to determine the reproductive aspects (sex ratio, spawning season, length at first sexual maturity and fecundity) of E. summana and E. polyphekadion for their proper management. Results of the reproductive biology can be used to formulate recommendations on the possible regulations to fisheries management for these commercially valuable grouper species.

\section{MATERIALS AND METHODS}

A total of 246 specimens (125 of E. summana and 121 of E. polyphekadion) were collected from the main landing sites on the Egyptian Red Sea (Hurghada and Shalateen) from 2017 to 2019. Samples were transported to the Lab. Total lengths to the nearest millimeter and total weights to the nearest gram were recorded. Then samples were dissected for sex determination. Maturity stages were recorded and gonads were weighed to the nearest $0.01 \mathrm{~g}$. All ovaries and testes were assigned a macroscopic stage based on El Ganainy (1992) and Osman et al, (2020) where, I undifferentiated gonad (threadlike), II immature, III developing, IV ripe, V spawning (running) and VI spent.

Sex ratio was determined as the percentage of males to females (M: F). The variations of sex ratio for both investigated species were estimated monthly and for the different length groups. A chi-square test (at 5\% significance level) was computed according to Snedecor (1956).

The condition and development of the gonads were studied by applying the Gonado-Somatic Index according to Anderson \& Gutreuter (1983) in which the gonad weight can be related to fish weight:-

\section{G.S.I= [Gonad weight $($ GW) $/$ Total fish weight $($ TW $)] \times 100$}

Length at first sexual maturity $\left(\mathrm{L}_{\mathrm{T} 50}\right)$, the length at which $50 \%$ of males and females of each species attain maturity was derived, according to White (2007), from the following logistic regression, where the proportion $\left(\mathbf{P}_{\mathbf{L}}\right)$ of those individuals that were mature at length $\mathbf{L}_{\mathbf{T}}$ was calculated as,

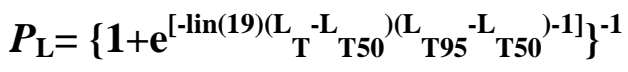


Where, $\mathrm{L}_{\mathrm{T} 50}$ and $\mathrm{L}_{\mathrm{T} 95}$ are Parameters for the logistic regressions fitted to the total length $\left(\mathrm{L}_{\mathrm{T}}\right)$ at maturity data.

Interviews with fishermen at different landing sites in the Egyptian Red Sea were used for mapping of some groupers spawning aggregation sites. The questionnaire included questions concerning the fishermen observations of spawning aggregation sites, species of grouper, spawning periods and water depth at spawning sites.

Fecundity was estimated by counting the number of mature ova in a known weight of mature/ripe ovary according to Sujatha et al. (2015). Using the following formula:

Absolute fecundity $=($ No. of ova in the subsample $\mathrm{x}$ total ovary weight $) /$ Weight of subsample

Relative fecundity was obtained by dividing absolute fecundity by total weight of the fish.

The relation of fecundity "F" with total length "TL", and total weight "TW" was estimated as per the formula given by Bagenal (1978):

$$
\mathbf{F}=\mathbf{a} \mathbf{T L}^{\mathbf{b}} ; \mathbf{F}=\mathbf{a} \mathbf{T W}^{\mathbf{b}}
$$

Where, $\mathrm{a}$ and $\mathrm{b}$ are constants, TL is the total length $(\mathrm{cm})$, TW is the body weight $(\mathrm{g})$.

\section{RESULTS}

\section{Sex ratio}

Females constituted about $53.7 \%, 45.5 \%$ males and $0.8 \%$ hermaphrodite of the $E$. summana samples and the E. polyphekadion samples constituted about $57 \%$ females and $47 \%$ males. The overall sex ratio of males to females was 1:1.2 for E. summana and 1:1.3 for E. polyphekadion which was non-significantly different from the ideal sex ratio of 1:1 (as the $P$ value was 0.32 and 0.12 for E. summana and E. polyphekadion, respectively). The percentage of males to females of both species varied within months and within length classes. For E. summana females were the dominant in all months except May and June, while for E. polyphekadion females were the dominant during all the months (Fig. 1). Females E. summana outnumbered males in the small length groups and absent in large $(>60 \mathrm{~cm})$ length groups, while in case of E. polyphekadion males were the dominant in the small length groups $(<32 \mathrm{~cm})$ and females were the most dominant in larger length groups (Fig. 2). 

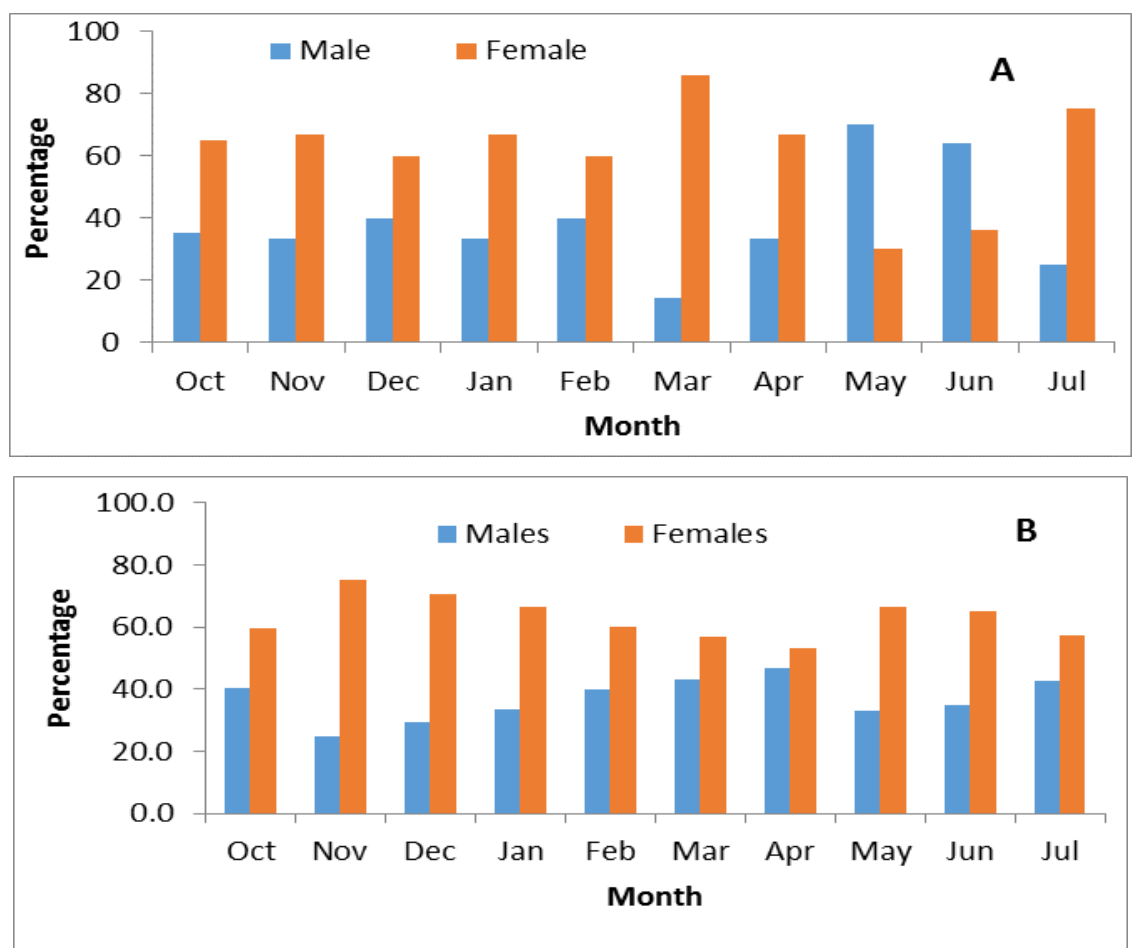

Fig (1): Monthly variations in percentage of male to female of E. summana (A) and $E$. polyphekadion (B) from the Red Sea.
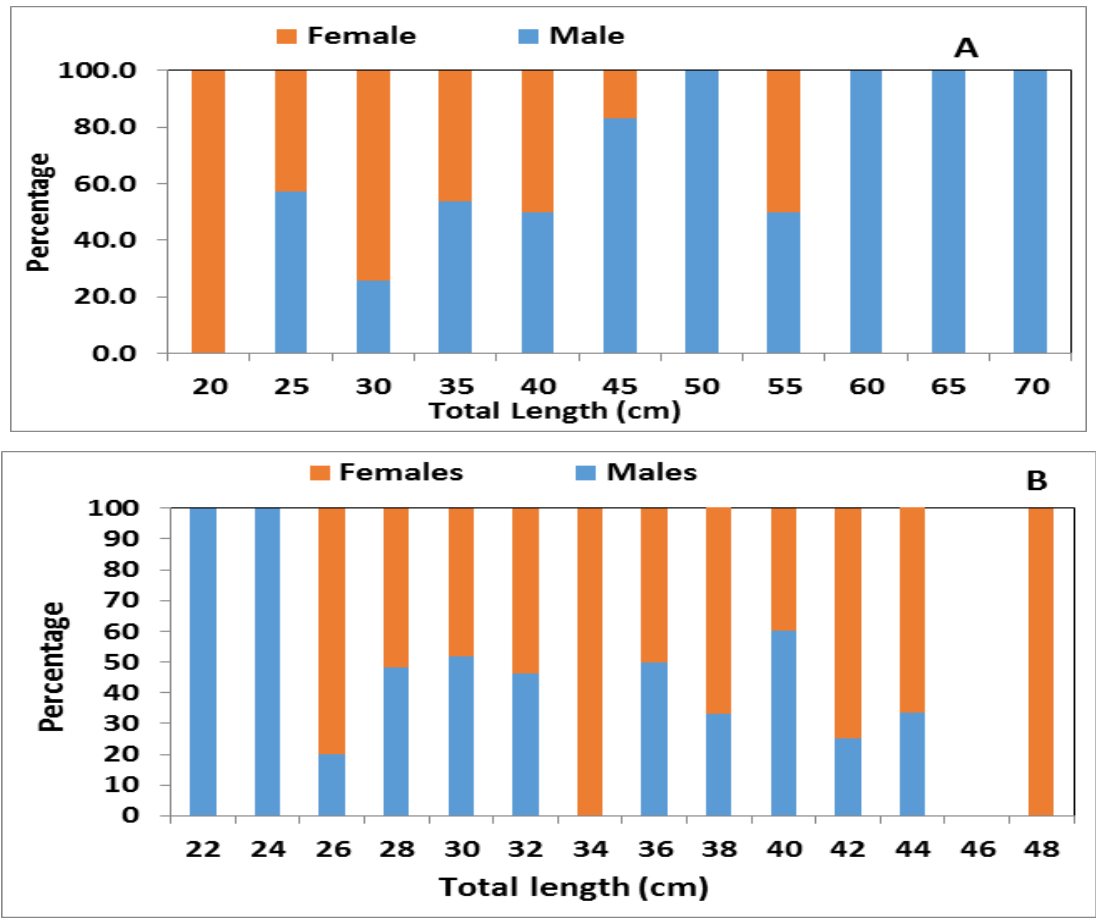

Fig (2): Percentage of males and females in different length groups for E. summana (A) and E. polyphekadion (B) in the Red Sea 


\section{Sexual pattern}

On the basis of their macroscopic appearance, there are differentiations in gonad maturity conditions according to different seasons. The ripe stages of female and male $E$. summana started to appear in late winter and extended to spring season with high percent, and then the spawning stage (running) appeared in spring and extended to summer season. In summer, the most dominant stage for E. summana were spent and recovery stage. During autumn all samples of E. summana were in immature and recovery stages (Fig. 3).

E. polyphekadion also have variation in gonad maturity conditions in different seasons. Maturing or developing stage started during late winter for both male and female, then during spring the ripeness and running stage (spawning) are dominant. During summer most of samples become spent. In autumn all samples are immature and recovery stages (Fig. 4).
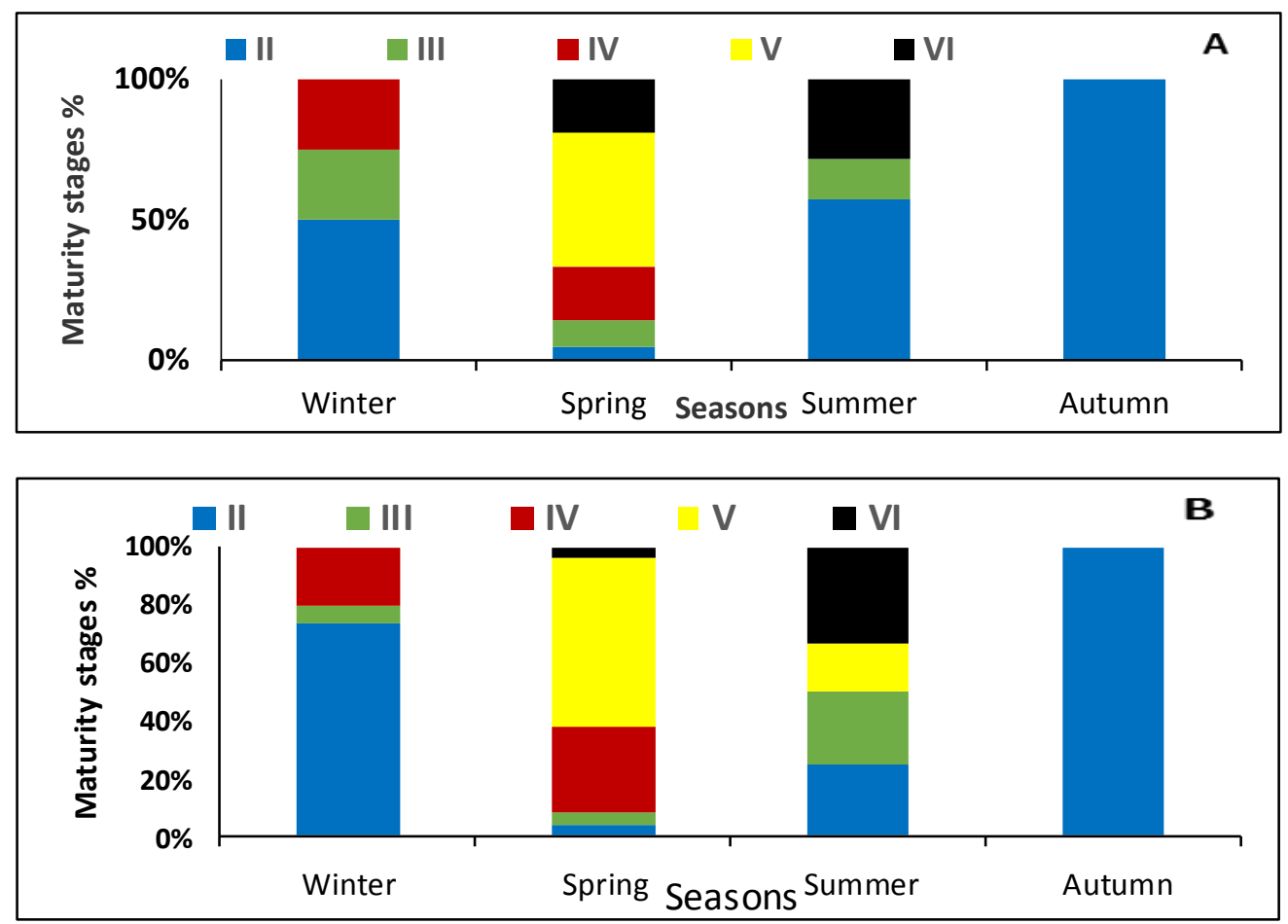

Fig (3): Seasonal variations in percentage of gonad maturity stages for males (A) and females (B) E. summana, Maturity stages: II: immature, III: developing, V: ripe, V: runing (spawning) and VI: spent 

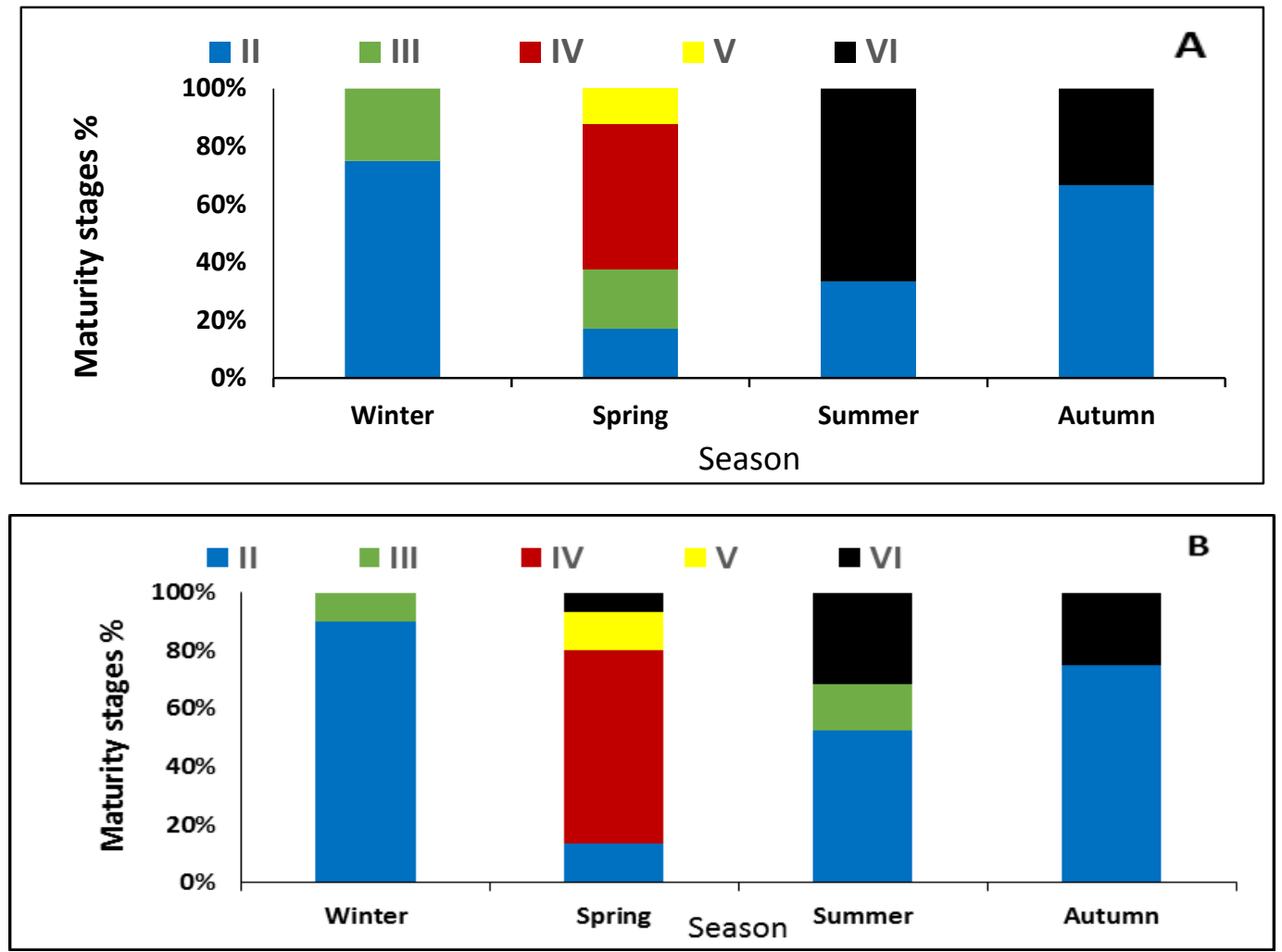

Fig (4): Seasonal variations in percentage of gonad maturity stages for males (A) and females (B) E. polyphekadion, Maturity stages: II: immature, III: developing, V: ripe, V: runing (spawning) and VI: spent

\section{Gonado somatic index (GSI)}

Females acquired higher average values of GSI than males for both studied species. The trend of average values of GSI for males and females were nearly similar; average value of GSI increased in April and reached its peak in May for E. summana while it started to increase in May then reached its peak in June for E. polyphekadion (Fig. 5).
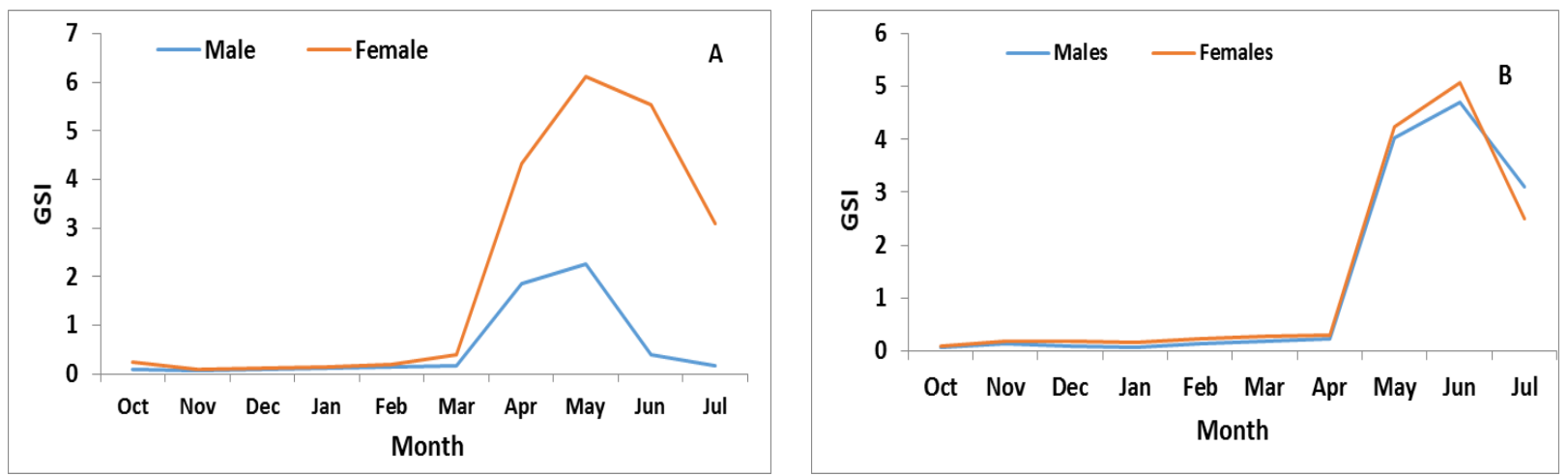

Fig (5): Monthly variations of gonadosomatic index (GSI) for E. summana (A) and $E$. polyphekadion (B) 


\section{Length at first sexual maturity $\left(\mathrm{L}_{\mathrm{m}} \mathrm{w}_{0}\right)$ :}

Results showed that males of both studied species matured slightly earlier than females. For E. summana, the length at first maturity $\left(\mathrm{L}_{\mathrm{m} 50}\right)$ was $23.0 \mathrm{~cm}$ for males and $23.5 \mathrm{~cm}$ for females, while for E. polyphekadion, the length at first maturity $\left(\mathrm{L}_{\mathrm{m} 50}\right)$ was $27.1 \mathrm{~cm}$ and $28.8 \mathrm{~cm}$ for males and females, respectively (Fig. 6).

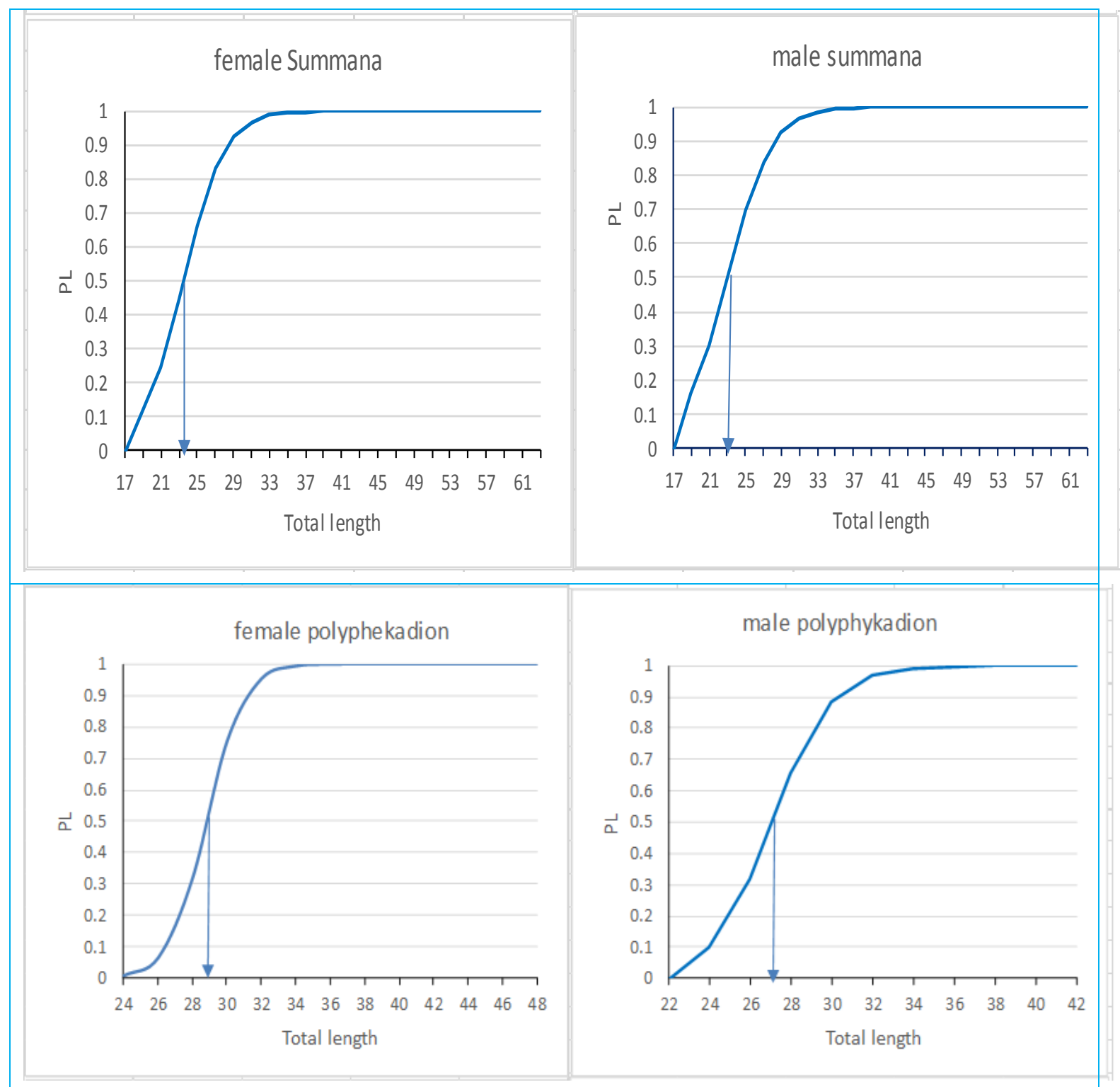

Fig (6): length at first sexual maturity for males and females E. summana and $E$. polyphekadion 


\section{Spawning aggregation sites}

According to the questionnaires and interviews conducted with fishermen, the summana grouper and the camouflage grouper spawn in the same spawning aggregation sites with some other grouper species such as E. tauvina and Cephalopholis miniata. These sites occur near the small scattered islands of the Red Sea at depths of 20-50 m, in the seaward reef slope (Fig. 7).
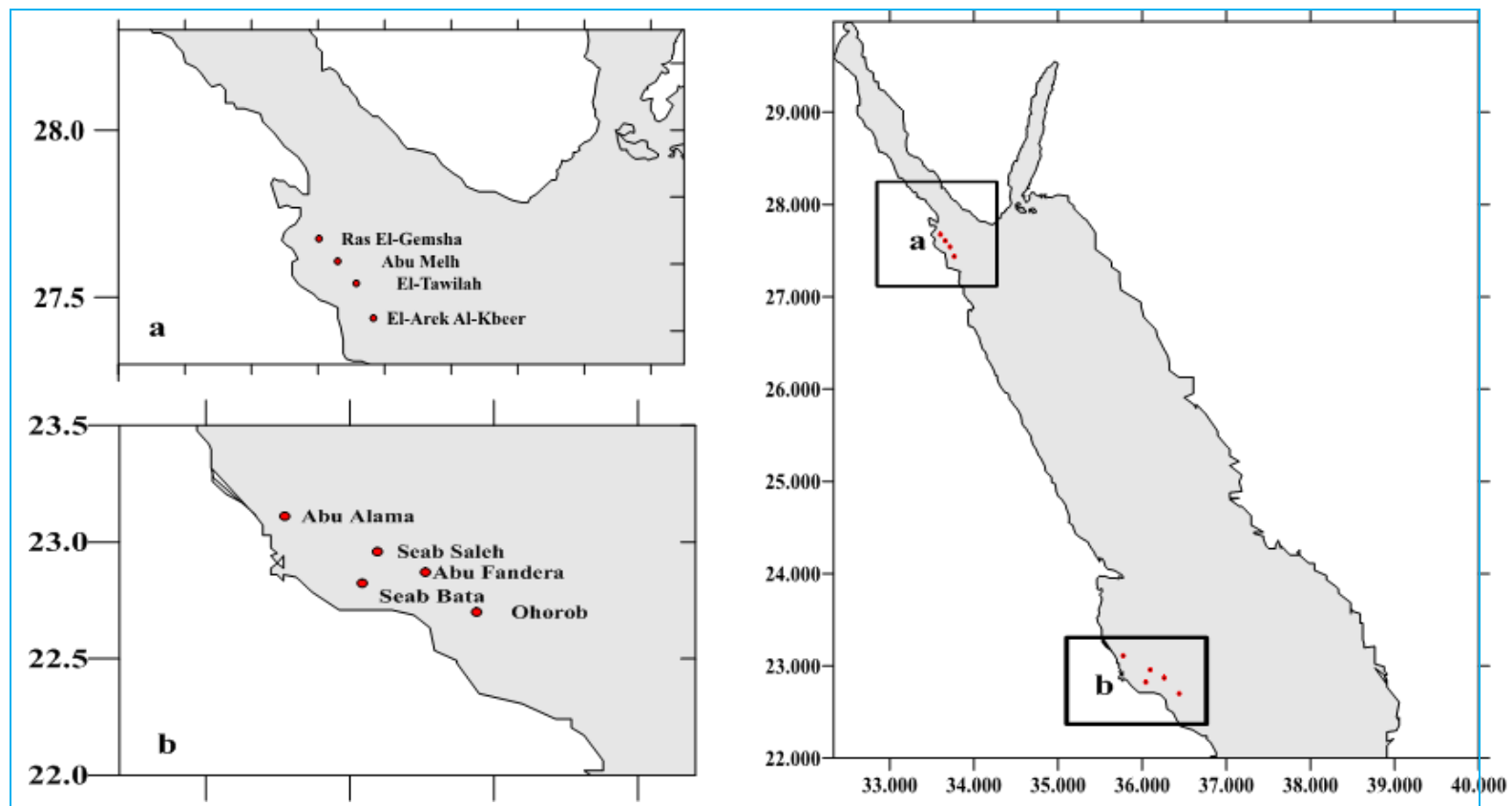

Fig (7): Spawning aggregation sites of E. summana and E. polyphekadion in the Red Sea. $a=$ Hurghada and $b=$ Shalateen..

\section{Fecundity:}

\subsection{Absolute fecundity:}

Number of eggs in ripe ovaries of E. summana during spawning season (May \& June) showed that the absolute fecundity ranged from 327680 eggs to 1250430 eggs with an average of 892409 eggs. The absolute fecundity of E. polyphekadion ranged from 203600 to 1110117 with an average of 726642 eggs.

\subsection{Relative fecundity}

The relative fecundity is defined as the number of eggs in ripe ovaries per unit weight of the fish. The relative fecundity for E. summana ranged from 519.5 to 1491.8 with an average of 1009.4 oocytes $\mathrm{g}^{-1}$., while that of $E$. polyphekadion ranged from 533.1 to 996.4 with an average of 775.5 oocytes $\mathrm{g}^{-1}$.

\subsection{Fecundity-total length relationship:}

Absolute fecundity increased as the fish grows in length. The absolute fecundity ranged from 327680 eggs to 1250430 eggs for fish length ranging from 32 to $37.6 \mathrm{~cm}$. 
The regression equation for the absolute fecundity and fish length of $E$. summana (Fig. 8A) was:

$$
\log F=-3.0179+5.7152 \log L \quad\left(R^{2}=0.65\right) .
$$

Absolute fecundity of E. polyphekadion ranged from 203600 to 1110117 for fish length ranging from $28.7 \mathrm{~cm}$ to $43.5 \mathrm{~cm}$. The regression equation between the absolute fecundity and fish length (Fig. 8B) was:

$$
\log \mathrm{F}=0.2858+3.5357 \log \mathrm{L} \quad\left(\mathrm{R}^{2}=\mathbf{0 . 8 9}\right) .
$$

\subsection{Fecundity-total weight relationship:}

The average absolute fecundity related to total weight of E. summana is represented in Fig. (9A). Regression equation between the absolute fecundity and fish weight was:

\section{$\log \mathrm{F}=\mathbf{0 . 7 7 5 9}+1.7543 \log \mathrm{W}$}

While the average absolute fecundity related to total weight of E. polyphekadion is represented in Fig. (9B). Regression equation between the absolute fecundity and fish weight was:

\section{$\log F=2.5724+1.1063 \log W$}
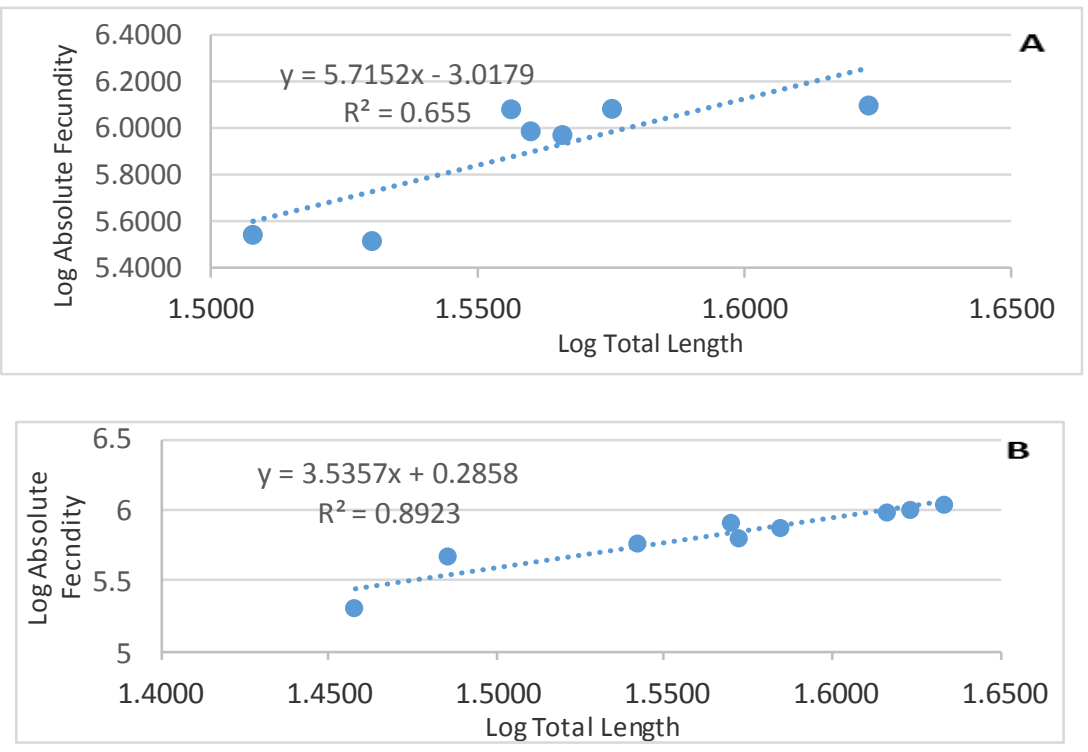

Fig (8): Relation between absolute fecundity and total length of E. summana (A) and E. polyphekadion (B). 


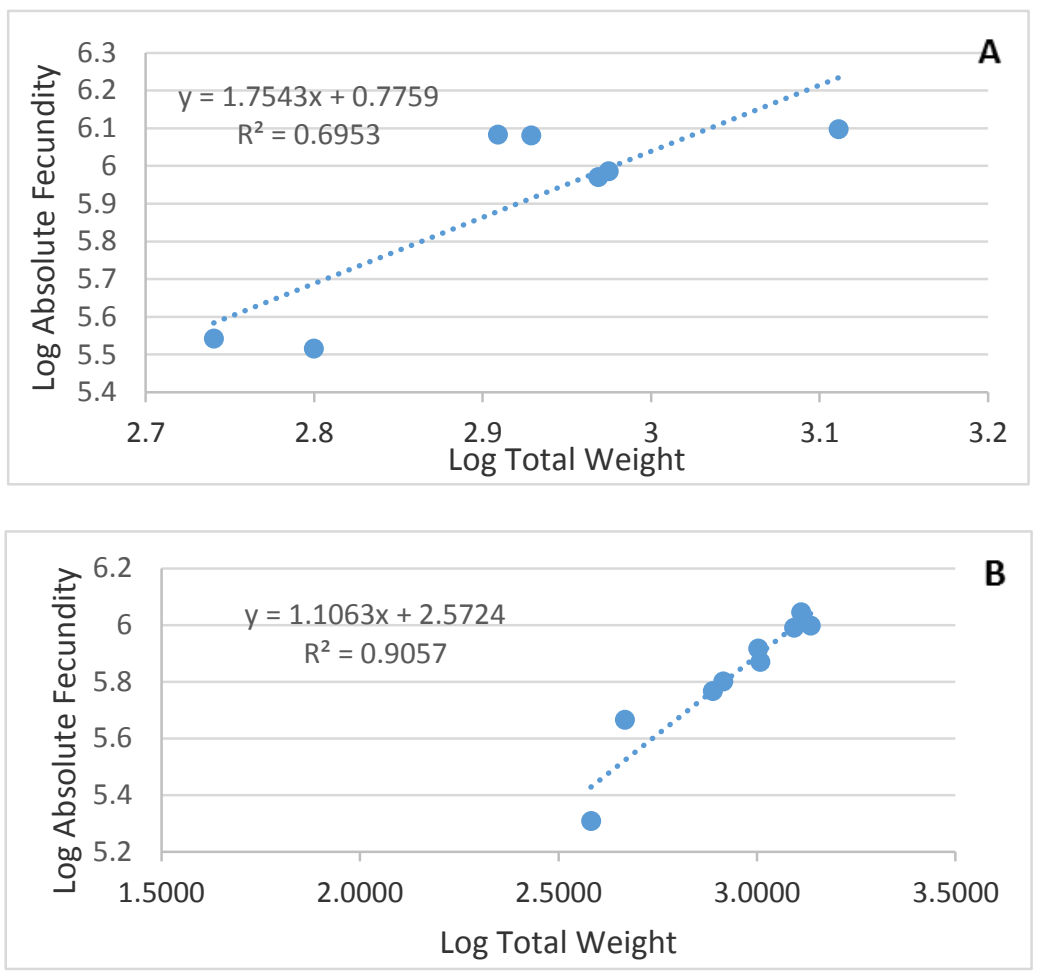

Fig (9): Relation between absolute fecundity and total weight of $E$. summana (A) and $E$. polyphekadion $(\mathrm{B})$.

\section{DISCUSSION}

Reproduction is one of the most important biological characters which should be studied for fisheries management (El Ganainy, 2004; Osman, et al., 2020). It gives the predictable future for fish production and new recruit adding for the recent stock. The reproductive ability of female is responsible for the new recruit (El Ganainy et al., 2014; Osman, 2016). The reproductive biology of the summana grouper, E. summana and camouflage grouper, E. polyphekadion is described in terms of their sex ratio, spawning season, sexual pattern, size at maturity and fecundity.

The overall sex ratio of both species is biased in favor of females. For $E$. summana, males outnumbered females during May and June, the spawning period; this is most probably due to the migration to spawning aggregation sites. Females of $E$. summana were dominant at smaller fish sizes and absent among larger fish sizes, this is typical for haremic protogynous species, where males attain a larger size in order to defend their territories or spawning sites that females visit (Warner et al., 1975; Warner, 1984). Furthermore, the obvious decrease in the proportion of females above the mean size at sexual maturity indicated that a sex change occurs as females become larger. Conversely, females of E. polyphekadion dominated the large sizes and were absent in the smaller fish sizes. The variability of sex composition can be attributed to the selective natural and fishing mortalities between sexes which may be a result of differential fishing pressure on males and females in the non-spawning periods (Johannes et al., 1996). 
Epinephelines exhibit a wide diversity of sexual patterns, including sequential and bi-directional hermaphroditism, and gonochorism (Shapiro 1987; Sadovy et al., 2008). Protogynous hermaphroditism has been the most commonly observed pattern. The size structure of E. summana and the presence of bisexual individual $(34 \mathrm{~cm}$. TL) provide an evidence that this species is a protogynous hermaphrodite. The female biased sex ratio and larger body size of male fish are typical of haremic protogynous species (Sadovy \& Shapiro, 1987). Considering that this is the first study on these species in the Egyptian Red Sea, further research is required.

For the camouflage grouper E. polyphekadion no evidence was obtained to confirm hermaphroditism, this is in agreement with Khasana et al. (2019). According to Rhodes \& Sadovy (2002), it was not possible to confirm sexual pattern in $E$. polyphekadion. In contrast, plausible evidence for protogyny was provided by a tagrecapture study, where 2 tagged females were later recovered as males (Johannes et al. 1999). Rhodes et al. (2011) confirmed that E. polyphekadion is a functional gonochorism with the potential for protogynous sexual transition; they postulated that the factors contributing to the regional variation observed in E. polyphekadion sexual pattern are unknown, but highlight the complexity of reproductive development.

Groupers tend to spawn from early spring to early summer and they are reproductively active over 1-5 months (Thresher, 1984; Shapiro, 1987) which is the case in the present study where, both investigated species spawn during a two consecutive months between April and May in case of E. summana and between May and June for $E$. polyphekadion. The camouflage groupers spawn during three consecutive months (February to April) in Pohnpei, Micronesia (Rhodes \& Mitcheson, 2002). Rhodes \& Mitcheson (2002) and Rhodes et al. (2018) reported that the camouflage grouper has a spawning peak in late January and April during the last quarter moon phase. Rhodes \& Sadovy (2002) reported that the camouflage grouper spawns during a two consecutive month period between February and April and form transient spawning aggregations that persist over approximately two weeks within each month. Teruya et al. (2008) in Ishigaki Island concluded that the main spawning season of the wild camouflage groupers is during April and May, when the GSI values of females and males reached the peak. According to Khasana et al. (2019) the spawning of E. polyphekadion begins in late September and continues until early April. Rhodes \& Sadovy (2002) indicated that the spawning season of camouflage groupers at several sites from the northern to southern hemispheres occurs over a 2-3 month period with great seasonal variations. The spawning season of serranids differs depending on the geographical area and species (James et al., 1997; Lee et al., 2002 and Rhodes \& Sadovy, 2002).

The length at first maturity $\mathrm{L}_{50 \%}$ is an important characteristic of life history, essential for prosperity of fishery management and fundamental to establishment of the means that avoid exploitation of young specimens and consequential reduction of spawning stock (Penha \& Mateus, 2007). In the present study, the estimated $\mathrm{L}_{50 \%}$ for summana grouper was $23.0 \mathrm{~cm}$ for males and $23.5 \mathrm{~cm}$ for females. Our results of the size at first maturity of the camouflage grouper agree with that reported by Rhodes \& Mitcheson (2002) in Pohnpei, Micronesia and smaller than that reported by Khasana et al. (2019) in Indonesia which was $37.0 \mathrm{~cm}$. 
Many reef fishes particularly groupers are known to aggregate in large numbers at specific times and places to reproduce. The detection of aggregation sites is essential for the development of a management plan and establishing of aggregation-based protected areas. Spawning aggregations have been completely obliterated by overfishing at a number of locations in the Atlantic and the Pacific oceans (Johannes et al., 1999). The camouflage grouper E. polyphekadion aggregation sites are known at some few locations, such as in Pohnpei, Micronesia (Rhodes \& Sadovy 2002) and Wakatobi, Indonesia (Khasana et al., 2019). In the Red Sea, these aggregation sites were defined for the first time according to information obtained from local fishers. Based on this primarily information establishing fishing closures during the brief annual spawning aggregation periods of groupers might be an effective approach to protect this valuable resource.

E. polyphekadion and E. summana were characterized by high fecundity. Absolute fecundity ranged from 203600 to 1110117 with an average of 726642 eggs for $E$. polyphekadion. It ranged from 327680 eggs to 1250430 eggs with an average of 892409 eggs for E. summana. The average relative fecundity was 775.5 oocytes $\mathrm{g}^{-1}$. and 1009.4 oocytes $\mathrm{g}^{-1}$ for $E$. polyphekadion and E. summana, respectively. These results fall within the range of fecundity previously estimated for other serranids (Bouain \& Siau, 1983; Shapiro, 1987). Rhodes \& Sadovy (2002) estimated the absolute fecundity for $E$ polyphekadion in Micronesia ranged from 392,000 oocytes in a 290-mm SL individual to more than 3.1 million oocytes in a $430-\mathrm{mm}$ SL individual.

\section{CONCLUSION}

This is the first study investigating the life history characteristics of E. summana in the Red Sea and thus could contribute towards the revision of its current IUCN red list status as "Data Deficient". Results on the life history characteristics of these species will add to the requirements of managing the exploitation of these valuable resources. Further studies should be undertaken to define the spawning aggregation sites of groupers in the Red Sea for establishing of aggregation-based protected areas and seasons

\section{REFERENCES}

Abdul Kader, N.H.; Rumeaida, M.P.; Ambak, M.A., and Musa, N. 2016. Reproductive aspects of aerolate grouper, E. aerolatus and six-barred grouper E. sexfaciatus from Terengganu waters, Malaysia. AACL.Bioflux. 9 (6): 1372-1379. http://www. bioflux. com.ro/aacl

Ambak, M.Z.; Isa, M.M.; Zakaria, M.Z. and Ghaffar, M.A. 2012. Fishes of Malysia. $2^{\text {nd }}$ edition. Kuala. Terengganu, penerbit UMT, 301pp.

Anderson, R. O. and Gutreuter, S. J. 1983. Length, weight and associated structural indices. In: Fisheries techniques (Eds. Nielsen L and Johnson D), American Fisheries Society, Bethesda,MD., pp.284-300.

Bagenal, T.B. 1978. Aspect of fish fecundity. pp. 75-101. In: Ecology of Freshwater Fish Production (ed. S.D. Gerking), Blackwell Scientific Publications, Oxford, UK. 
Bouain, A. and Y. Siau. 1983. Observations on the female reproductive cycle and fecundity of three groupers (Epinephelus) from the southeast Tunisian seashores. Mar. Biol (Berl.) 73: 211-220.

Bolden, S.K., 2000. Long-distance movement of a Nassau grouper (Epinephelus striatus) to a spawning aggregation in the central Bahamas. Fishery Bull. Nat. Oceanic Atmospheric Administration, 98: 642-645.

Carter, H.J.; G.J. Marrow and Pryor V. 1994. Aspects of the ecology and reproduction of Nassau grouper, Epinephelus striatus, off the coast of Belize, Central America. Proc. Gulf Carib. Fish.Inst. 43: 65-111.

El Ganainy, A. A. 1992. Biological studies on Lizard fishes Saurida undosquamous (Pisces, Synodontidae) from the Gulf of Suez. M.Sc. thesis, Zool. Dep. Fac. Sci. Ain shams Univ. Egypt.

El-Ganainy, A. A., 2004. Biological characteristics and fishery assessment of the lizard fish Saurida undosquamis from the Red Sea, Egypt. Egypt. J. Aquat. Biol. \& Fish., 8(2):93-113.

El Ganainy A. A.; Abd El-Rahman A.A.; Rizkalla W.; El-Shabaka H. A. and AboMesalem M. A., 2014. Age, growth and reproductive biology of the keeled mullet Liza carinata from the Suez Bay, Red Sea, Egypt. Egypt. J. Aquat. Biol. \& Fish. (18): 1-8. ISSN $1110-6131$

El Ganainy, A.A. 2017. stock assessment and gear description of the Red Sea and Gulf of Suez fisheries for their proper management. Final report submitted to Sience and Technology Development Fund STDF, Ministry of scientific Research, Egypt.124pp.

Grandcourt, E. M.; Al abdessalam, T.Z.; Francis, F.; Shamsi, A.T. and Hartman, .S.A., 2009. Reproductive biology and implications for management of the orange spotted grouper E. coioides in the southern Arabian gulf. Jour. Of fisheries biology, 74: 820841.

GAFRD 2017. Annual statistical Report of General Authority for Fish Resources Development 2017.

James, C. M.; AI-Thobaiti, S. A.; Rasem B. M. and Carlos M. H. 1997. Breeding and larval rearing of the camouflage grouper Epinephelus polyphekadion (Bleeker) in the hypersaline waters of the Red Sea coast of Saudi Arabia. Aquacult. Res., 28: 671681.

Johannes, B.; Squire, L.; Graham, T.; Renguul, H., and Bukurrou, A. 1996. Palau grouper spawning aggregation research project 1995 progress report. Prog. Rep. Forum Fish. Agency, Honiara, Solomon Islands.

Johannes, R. E.; Squire, L.; Graham, T.; Sadovy, Y. and Renguul, R. 1999. Spawning Aggregations of Groupers (Serranidae) in Palau. The Nature Conservancy Marine Conservation Research Series Publication; 1: 144 pp.

Kandula S.; Shrikanya K. V. L. and Deepti V. A. I. 2015. Species diversity and some aspects of reproductive biology and life history of groupers (Pisces: 
Serranidae:Epinephelinae) off the central eastern coast of India. Marine Biology Research 11(1):18-33.

Khasanah, M.; Kadir,N..N. and Jompa, J. 2019. Reproductive Biology of Three Important Threatened/Near-Threatened Groupers (Plectropomus leopardus, Epinephelus polyphekadion and Plectropomus areolatus) in Eastern Indonesia and Implications for Management. Animals, 9: 643. 1-18.

Lee, Y. D.; Park, S. H. Takemura A. and K. Takano 2002. Histological observations of seasonal reproductive and lunar-related spawning cycles in the female honeycomb grouper Epinephelus merra in Okinawan waters. Fish. Sci., 68: 872-877.

Nelson, J.S. 1994. Fishes of the world. $3^{\text {rd }}$ Edition. John Wiley \& Sons

Osman, H. M. 2016. Biological and Fisheries Studies on Barracuda Fish (Family: Sphyraenidae) in the Gulf of Suez. Ph.D. Thesis, Fac. Sci. Suez Canal, Uni. Ismailia, Egypt.

Osman, M. H.; El Ganainy, A. A.; Shaaban, A.M.; Saber, M. A.; Amin A.M. and Ahmed, A.S., 2020. Characterization of the reproductive biology of the Sparid fish: Rhabdosargus haffara in Suez Bay, Red Sea. Egyptian Journal of Aquatic Biology \& Fisheries. 24(1): 83-90.

Penha, J.M.F. and L.A.F. Mateus 2007. Sustainable harvest of two large predatory Catfish in the Cuiabá river basin, northern Pantanal, Brazil. Brazilian Journal of Biology; 67(1):81-89.

Rhodes, K.L. and Mitcheson, Y.S.2002. Reproduction in the Camouflage Grouper Federated States of Micronesia (Pisces: Serranidae) in Pohnpei. Bull. Mar. Sci., 70: 851-869.

Rhodes, K. L. and Sadovy, Y. 2002. Temporal and spatial trends in spawning aggregation of camouflage grouper, Epinephelus polyphekadion, in Pohnpei, Micronesia. Env. Biol. Fish., 63. 27-39.

Rhodes 1, K.L.;Taylor, B. M. and McIlwain, J.L. 2011. Detailed demographic analysis of an Epinephelus polyphekadion spawning aggregation and fishery. Mar Ecol Prog Ser. 421: 183-198. https://doi.org 10.3354/meps0890

Rhodes, K.; Choat, J.H.; Sadovy, Y.; Myers, R.; To, A.; Ma, K.; Samoilys, M.; Suharti, S.; Law, C. and Amorim, P. 2018. "Epinephelus polyphekadion," The IUCN Red List of Threatened Species. 2018. available online: http://dx.doi.org/10.2305/IUCN.UK. $\quad$ 2018-2.RLTS.T61339A100553967.en (accessed on 25 June 2019).

Sadovy Y. and Shapiro D.Y., 1987. Criteria for the diagnosis of hermaphroditism in fishes.Copeia 1:136-156.

Sadovy, Y.; de Mitcheson Y. and Liu M., 2008. Functional hermaphroditism in teleosts. Fish Fish 9:1-43.

Sadovy, Y., 2005. Trouble on the reef: The imperative for managing vulnerable and valuable fisheries. Fish Fish., 6: 167-185. 
Shapiro DY., 1987. Reproduction in groupers. In: Polovina JJ, Ralston S (eds) Tropical snappers and groupers: biology and fisheries management. Westview Press, Boulder, CO, 295-327.

Sendecore, G.W., 1956. Statistical methods. Applied to experiments in agricultural and biology of the low state university Press. U.S.A. 534pp.

Sujatha k.; kantimahanti, V. L. S.; Iswarya, V. A. D., 2015. Species Diversity and some Aspects of Reproductive biology and life history of groupers (Pisces: Serranidae: Epinephelinae) off the central eastern coast of India. Mar. Biol. Res. 11. 8-33.

Thresher, R.E. 1984. Reproduction in reef fishes. T.H.F. Publications, Neptune City. 399 pp.

Teruya, K.; Masuma, S.; Hondo, Y. and Kamasaki, K. 2008. Spawning Season, Lunarrelated Spawning and Mating Systems in the Camouflage Grouper Epinephelus polyphekadion at Ishigaki Island, Japan. Aquaculture Sci., 56 (3): 359-368.

Warner, R. R. 1984. "Mating behavior and hermaphroditism in coral reef fishes," American Scientist, 72 (2): 128-136.

Warner, R. R.; Robertson, D. R. and Leigh Jr. E. G., 1975. "Sex change and sexual selection," Science, 190 ( 4215): 633-638.

White, W. T. 2007. Catch composition and reproductive biology of whaler sharks (Carcharhiniformes: Carcharhinidae) caught by fisheries in Indonesia. Journal of Fish Biology, 71:1512-1540. 